\title{
Labour Market Adjustment and Women in the Service Industry: A Survey
}

\author{
Raymond Harbridge and Maryan Street*
}

\section{Introduction}

The celebration in 1993 of a century of women's suffrage in New Zealand has brought even more sharply into focus the uneven impact of the Employment Contracts Act on the workforce. From the outset, debate about the effects of the Employment Contracts Act had focused for some on the likely impacts on women workers. This study is located firmly within the tradition of national and international literature from a range of disciplines including economics, industrial relations, sociology, law and history, which describes a segmented labour market and labour process. One aspect of labour segmentation theory is gender segmentation, that is, the location of women and men in the labour market and their comparative situations. Much theoretical work and empirical research has been done to describe where women are located in the labour market, why they are located there, and what effects that location has upon them. Even within this field of study there is a wide range of subjects for analysis. For example, the subjects can range from the gender earning gap (Blau and Kahn, 1992) and occupational structures (Terrell, 1992) to the challenge of "flexibility" and the pool of labour women traditionally provide (Walby, 1989). Even the concept of "skill" itself has had to be revisited by the gender segmentation theorists (Bervoets and Frielink, 1988). Much of the theoretical framework within which these scholars cited have written, along with numerous others, was codified in the 1970s and 1980 s in response to Harry Braverman's classic mould-breaking work Labor and Monopoly Capital published in 1974. Writers such as Phillips and Taylor (1980), Cockburn (1981, $1983,1985)$ and Beechey (1982) remain some of the leading contributors to the discussion and ongoing analysis about women in the workforce. As industrial relations regimes and bargaining structures have altered in the $1980 \mathrm{~s}$ and on into the $1990 \mathrm{~s}$, the changes have been observed to impact differently upon different segments of the labour market.

Within New Zealand, concern about the disproportionate impact of the Employment Contracts Act upon women in the labour market was one aspect of the opposition voiced during the introduction and passage of the Act. The purpose of this study was to take a discrete and relatively homogenous group of women workers who were located in the same 
segment of the labour market, and assess the impact of the Employment Contracts Act on their wages and working conditions, in order to provide a fuller picture of the Act's impact across New Zealand's workforce.

Sayers (1991) was one to speculate on the Act's likely effects, identifying as key determinants the location of women in the workforce, bargaining issues and the impact of social policies on women's opportunities. Sayers identified women in three labour market areas: a group of elite, well-educated women with flexible work skills and enough resources to minimise the effects of family life on their paid employment; women working in clerical and service occupations (the vast majority); and women as participants in the informal economy, including women on benefits, homeworkers, part-time workers, the unemployed and voluntary workers. Bargaining structures emerging under the Employment Contracts Act, with its promotion of individualism over collectivism, would affect these groups differently. Sayers stressed women's vulnerability in bargaining because of their own and men's socialisation, the perceived value of women's work, and the effects of structural inequalities such as earning and skill differentials. Sayers concluded (somewhat tentatively):

\begin{abstract}
Women in New Zealand society are solidly represented in this country's poor. They already make up the greater proportion of elderly people on Guaranteed Retirement Income, solo parents, the unemployed and those employed in the twilight economy. The Employment Contracts Act is unlikely to ensure that any "higher wages" coming from "higher productivity" will fall to those women who, for a significant proportion of their lifetimes, will be the primary household earner. (Sayers, 1991: 165).
\end{abstract}

Three years later, Sayers is on the way to being proven correct. Research by Hammond and Harbridge (1993) on 1,100 collective employment contracts covering 187,000 workers and approximately 8,300 employers has shown that men have been more likely than women to receive productivity based payments; women have been more likely than have men to be covered by contracts where overtime and penal rates have been reduced or removed; and women have on average received changes to basic pay rates that have been one third of those received by men. Women workers have received no advantages under the Employment Contracts Act but have seen considerable disadvantage from its implementation. Determining the exact extent of that disadvantage has, however, been problematic. Hammond and Harbridge have examined the content of collective employment contracts and have measured changes to clauses in employment conditions. They have not however been able to determine the accumulative effects of these changes as they have not surveyed employees to determine the practical application of these changes. Only by surveying actual employees and knowing how a contract applies in specific cases can the overall impact of changed employment contracts be identified.

As has been generally recognised, data collection on labour market adjustment and specifically collective bargaining has been fraught with difficulties since the implementation of the Employment Contracts Act. The Employment Contracts Act requires only contracts covering 20 or more employees to be lodged with the Department of Labour and compliance is acknowledged as a serious difficulty. In recognition of that difficulty, the Department of Labour commissioned a survey of labour market adjustment. The survey, by Heylen Research Centre and Teesdale, Meuli and Company, was undertaken in August 1992. The results were released later in the year (Heylen et al., 1992) and presented as an 
academic journal article (Armitage and Dunbar, 1993). It was a very useful survey, although not without its shortcomings. The survey sought quantitative data on bargaining structures, outcomes and representation, and qualitative data on bargaining issues and productivity. The qualitative work was carried out by means of case studies and the quantitative work relied on three separate surveys of workers, enterprise and directors. The surveys covered 1,000 workers, 1,437 enterprises employing 216,041 workers, and 500 company directors.

The Heylen survey revealed the extent, as best can be calculated, of the collapse of multiemployer agreements, an immediate reflection of the deregulatory impact of the Act on the former award structure. The proportion of employees on collective multi-employer agreements fell from 59 to eight percent in the period May 1991 - August 1992. Resulting from the collapse of these multi-employer agreements there was an associated rise in the percentage of workers covered by individual employment contracts - from 28 to 52 percent over the same period. These significant changes in the structures of contracts have profound effects on bargaining processes and comparative bargaining strength within those processes. These effects are most noticeably felt by those workers located in the peripheral or secondary labour market, that is, those employed in casualised work, part-time positions or low paid occupations which are vulnerable to competition from unemployed workers. The majority of such positions are held by women workers.

The survey also showed that with the decentralisation of bargaining to the enterprise level, enterprises had largely either made no changes, cut labour costs and union rights, or moved more strategically to enhance productivity and worker involvement (Armitage and Dunbar, 1993: 111). Each of these options, none of which is prescribed in the Employment Contracts Act, may impact differently on women workers from men workers because of their predominant location in the labour market. In addition, changes tend to have occurred in the larger enterprises (employing more than 100 employees) rather than the smaller ones. Armitage and Dunbar refer to the gaps in the survey's sample base, namely the exclusion of employees who had a different job in August 1992 from that they had in May 1991. While this exclusion was undertaken so as to more clearly pinpoint the extent of actual changes resulting from the Act, it did mask the effects of the Act on new employees especially those employed on inferior conditions to those that had previously applied. The survey also excluded enterprises set up after May 1991, limiting the assessment of the Act's effect on easing conditions under which new enterprises might be established.

To more specifically identify the impact of the Employment Contracts Act and changed bargaining patterns on women workers, the Service Workers Union agreed to take part in a major survey of employment conditions as they applied pre and post the Employment Contracts Act. This paper reports the findings of that survey and reviews these findings in comparison to those produced by the Heylen survey. 


\section{Method}

The Service Workers Union is one of New Zealand's largest unions. Its most recent configuration is the result of a series of union amalgamations started in the mid 1980s when the Hotel and Hospital Workers Industrial Association merged with the Caretakers and Cleaners Industrial Association forming the Service Workers Federation. By May 1991, the affiliates of this Federation (regional hotel workers unions, caretakers and cleaners unions and theatrical workers unions) formed the Service Workers Union. More recently the (former) Northern Clerical Workers Union (COMPASS), the Musicians Union and the Community Service Workers Union have also affiliated. The Union has six divisions: hospitality; health (including Rest Homes); commercial (cleaners, caretakers and security workers); education (cleaners and caretakers); entertainment (musicians, theatre and race course workers); and COMPASS (clerks).

The union then has members who are employees in hotels, restaurants and hospitals; are employees undertaking clerical work, caretakers and cleaners; and are employees in the voluntary welfare sector. The location of many of these employees (and potential union members) closely aligns with Sayers' second (and largest) group of women in the labour market - those women in clerical and service occupations. The Service Workers Union was thus an ideal union to survey so as to identify the impact of the Employment Contracts Act on women employees.

The union presently has some 40,000 members representing some 25,000 full-time equivalent workers. Membership records are maintained on a computer system. For this survey, a selection programme identified all current, female union members with a home address listed in the union's membership records. Every fifth person so listed was then identified. This resulted in slightly more than 4,000 labels being generated. These were manually checked and a number of labels (just over 330) were removed. There were two main reasons for removal - first, some of the names were clearly male; second, some of the addresses were for a Company Head Office rather than a home address. It was decided not to send this survey to Company Head Offices as this method of contacting employees can be unreliable. Respondents were guaranteed that their responses would be treated as confidential and were supplied with a reply paid envelope.

In total 3,670 surveys were posted out in June 1993. Forty-three were returned "gone no address" leaving a net post-out of 3,627. Four weeks after being posted out, the union had received 962 returns - a response rate of 27 percent which is very acceptable for a survey of this type. The usual expectation and experience of written questionnaires in New Zealand is a response rate of about one third. There are two factors which make a response rate of 27 percent in this instance acceptable: the first is that the population being surveyed has the characteristics frequently associated with non-respondents (e.g. more likely not to have English as a first language than a random sample of the whole population, less well educated and therefore less likely to respond in writing); the second is that the total sample population of 3,627 is more homogenous than a random sample of the whole population might be, in that they are all women members of the Service Worker's Union. Given that this was the population being surveyed, the data gained from the 962 returns still represent useful information on women located in this segment of the labour market despite the 
response rate falling slightly below the traditional one third. To confirm that only women members had been sent the survey forms, each respondent was asked to state their gender. Just two responses were from men. These were excluded from the results. The responses have been coded and processed. The results of the survey follow.

\section{Results}

The sample is of an older age group of women - just 17 percent were under 30 years of age and 60 percent were over 40 years of age. Slightly more than 80 percent were "European" while 12 percent were Maori and five percent were Pacific Island Polynesian. This mix of ethnic groups approximates that in New Zealand society as a whole.

Surprisingly, many of these women members do not live with anyone who is dependent on them. Some 43 percent of respondents stated that they did not live with dependent people. About 10 percent have preschoolers and about one third have school age children. Slightly more than 10 percent have a dependent working age adult living with them. Each respondent was asked to indicate their occupation and the industry in which they were employed. The data are presented in Table 1.

Table 1: Occupation and industry of respondents

\begin{tabular}{||l|c|c|l|c|c||}
\hline \hline Occupation & Freq & Percent & Industry & Freq & Percent \\
& & & & & \\
\hline Receptionist & 57 & 6 & Rest Home & 115 & 12 \\
Cleanerlhousekeeper & 328 & 35 & Health & 180 & 19 \\
Clerk & 128 & 14 & School & 207 & 22 \\
Waitress & 50 & 5 & Restaurants & 53 & 6 \\
Nurse aidlcaregiver & 72 & 8 & Social agency & 35 & 4 \\
Home assistant & 43 & 4 & Hotel etc. & 100 & 11 \\
Bartender & 38 & 4 & Travel/airline & 52 & 6 \\
Other & 227 & 24 & Other & 186 & 20 \\
& & & & 928 & $100 \%$ \\
\hline Total & 943 & $100 \%$ & Total & & \\
\hline
\end{tabular}

Most respondents (83 percent) had just one job with 13 percent holding two jobs. Nearly 60 percent were part-time workers. The distribution of hours worked each week is presented in Table 2. Sixty percent of respondents indicated that they would work extra hours if they were offered them - many did not indicate how many additional hours they would work but, of those that did, commonly two additional hours per day would be accepted. Few of those surveyed held any union responsibilities. There were 47 union 
accepted. Few of those surveyed held any union responsibilities. There were 47 union delegates in the sample and four union executive members. Most of the respondents had been in their present employment for a considerable period of time. Just 13 percent had been in their present position for under two years.

Table 2: Average hours per week in paid employment each week

\begin{tabular}{||l|c|c||}
\hline & Frequency & Percent \\
\hline Under 10 hours & 69 & 7 \\
10-19 hours & 230 & 25 \\
20-29 hours & 213 & 23 \\
30-40 hours & 361 & 38 \\
Over 40 hours & 70 & 7 \\
\hline Total & 943 & 100 \\
\hline
\end{tabular}

Each respondent was asked to indicate the type of employment contract that covered their terms and conditions of work. Just over 70 percent indicated that they were covered by a collective employment contract, ten percent were covered by an individual contract and 20 percent responded that they "didn't know". Exactly 50 percent of respondents did not have a copy of their employment contract and one third indicated that they were not familiar with the contents of their employment contract.

Regarding the content of each respondent's employment contract and working conditions, the same questions as asked in the Heylen survey were posed. Two sets of questions were asked. The first set of responses concerned pay and related conditions over the last two years (since the introduction of the Employment Contracts Act). The data are presented in Table 3. The second set of questions related to leave.

Nearly one third of respondents have experienced an increase in basic pay rates, most are on the same pay rates, but ten percent have experienced a decrease in their basic hourly rates of pay. Overtime rates, weekend rates and other special payments or allowances have been reduced or abolished for more than 20 percent of respondents. Overall take home pay has gone down for 30 percent of respondents. 
Table 3: Changed pay, overtime and household income $(\mathrm{N}=962)$

\begin{tabular}{|c|c|c|c|c|c|c|}
\hline & $\begin{array}{l}\text { Gone } \\
\text { Up }\end{array}$ & $\begin{array}{l}\text { Stayed } \\
\text { Same }\end{array}$ & $\begin{array}{l}\text { Gone } \\
\text { Down }\end{array}$ & Abolished & $\begin{array}{l}\text { Not } \\
\text { Applic. }\end{array}$ & $\begin{array}{l}\text { Don't } \\
\text { Know }\end{array}$ \\
\hline $\begin{array}{l}\text { Basic Hourly Pay } \\
\text { Rates }\end{array}$ & $32 \%$ & $56 \%$ & $10 \%$ & - & - & $2 \%$ \\
\hline $\begin{array}{l}\text { Overtime Pay } \\
\text { Rates }\end{array}$ & $3 \%$ & $30 \%$ & $13 \%$ & $9 \%$ & $38 \%$ & $7 \%$ \\
\hline $\begin{array}{l}\text { Hours Worked } \\
\text { Before Overtime }\end{array}$ & $6 \%$ & $33 \%$ & $3 \%$ & $3 \%$ & $42 \%$ & $14 \%$ \\
\hline $\begin{array}{l}\text { Weekend Pay } \\
\text { Rates }\end{array}$ & $2 \%$ & $29 \%$ & $15 \%$ & $13 \%$ & $34 \%$ & $7 \%$ \\
\hline $\begin{array}{l}\text { Pay Rates Outside } \\
\text { Normal Hours }\end{array}$ & $2 \%$ & $26 \%$ & $8 \%$ & $6 \%$ & $47 \%$ & $12 \%$ \\
\hline $\begin{array}{l}\text { Special Payments } \\
\text { Allowances }\end{array}$ & $4 \%$ & $37 \%$ & $11 \%$ & $10 \%$ & $26 \%$ & $12 \%$ \\
\hline $\begin{array}{l}\text { Overall Take Home } \\
\text { Pay }\end{array}$ & $21 \%$ & $47 \%$ & $30 \%$ & - & - & $2 \%$ \\
\hline $\begin{array}{l}\text { Total Hours } \\
\text { Worked }\end{array}$ & $15 \%$ & $66 \%$ & $17 \%$ & - & - & $2 \%$ \\
\hline $\begin{array}{l}\text { Total Household } \\
\text { Income }\end{array}$ & $22 \%$ & $40 \%$ & $38 \%$ & - & - & - \\
\hline
\end{tabular}

Some ( 20 percent) have experienced an increase in take home pay but this is primarily a reflection of the fact that they are working additional hours. Fifteen percent of respondents are working longer hours than previously. There is a very significant relationship between changes to take home pay and changes to total hours worked. Workers who experienced an increase in take home pay were significantly more likely to be working longer hours than were other workers (Chi Square $=199 \mathrm{df}=4 \mathrm{p}<0.0001$ ). The data are presented in Table 4. 
Table 4: Changes to take home pay by changes to total hours worked

Total hours worked

\begin{tabular}{||l|l|c|c|c|c||}
\hline & & Gone Up & Same & Gone Down & Totals \\
\hline Take & Gone Up & 67 & 107 & 6 & 180 \\
Home & Same & 46 & 315 & 33 & 394 \\
Pay & Gone Down & 21 & 135 & 102 & 258 \\
\hline & Total & 134 & 557 & 141 & 832 \\
\hline
\end{tabular}

Changes to leave-based employment conditions were recorded. The data are presented in Table 5. Many respondents had already indicated they were unfamiliar with the content of their employment contract and this is confirmed when reviewing their responses to the questions regarding leave. Between 20 and 30 percent of respondents "didn't know" their entitlements to leave and further respondents did not believe that various types of leave were applicable to their circumstances. A small number of respondents experienced reductions in sick leave entitlements while others experienced reductions in the amount of leave they could accrue.

\section{Discussion}

The respondents are an older group of women, 60 percent of whom are part-time workers and 40 percent of whom are not living in New Zealand's six major cities. They work in small workplaces (40 percent have five or fewer co-workers), but have considerable continuity of employment with their current employer, as over 85 percent had been with their current employer for two or more years.

The information supplied about employment contracts here is very revealing. At the outset we sought to establish what had happened to each respondent's household income. Household income comes from a variety of sources - paid employment, welfare payments, and other incomes, from one or more adults in the household. Forty percent of respondents reported that their household income had gone down over the last two years while just 20 percent stated it had gone up. A primary cause of the "gone down" response is the direct effect of the Employment Contracts Act. This is confirmed by the finding that 30 percent of respondents reported that their overall take home pay had gone down. This reduction in overall take home pay did not, in most cases, come about through a reduction in basic hourly pay rates - rather it came about through the reduction in penal and overtime rates of pay. While few respondents had experienced reductions to basic pay rates, many had experienced reductions in overtime, weekend, night pay rates and reductions or the abolition of other special payments or allowances. When those who answered "not applicable" or "don't know" were excluded from the responses, 40 percent of respondents had experienced either a reduction to, or the abolition of, overtime pay rates; 48 percent had experienced 
Table 5: Changed rates of leave $(\mathrm{N}=962)$

\begin{tabular}{||l|c|c|c|c|c|c||}
\hline \hline & $\begin{array}{c}\text { Gone } \\
\text { Up }\end{array}$ & $\begin{array}{c}\text { Stayed } \\
\text { Same }\end{array}$ & $\begin{array}{c}\text { Gone } \\
\text { Down }\end{array}$ & Abolished & $\begin{array}{c}\text { Not } \\
\text { Applic. }\end{array}$ & $\begin{array}{c}\text { Don't } \\
\text { Know }\end{array}$ \\
\hline $\begin{array}{l}\text { Annual } \\
\text { holiday leave }\end{array}$ & $6 \%$ & $78 \%$ & $3 \%$ & - & $7 \%$ & $6 \%$ \\
Sick leave & $3 \%$ & $69 \%$ & $11 \%$ & $0 \%$ & $7 \%$ & $10 \%$ \\
$\begin{array}{l}\text { Extra leave } \\
\text { for long } \\
\text { service }\end{array}$ & $5 \%$ & $44 \%$ & $4 \%$ & $4 \%$ & $24 \%$ & $20 \%$ \\
$\begin{array}{l}\text { Special one- } \\
\text { off long } \\
\text { service hols }\end{array}$ & $1 \%$ & $34 \%$ & $3 \%$ & $4 \%$ & $32 \%$ & $27 \%$ \\
$\begin{array}{l}\text { Parental leave } \\
\begin{array}{l}\text { Bereavement } \\
\text { leave }\end{array}\end{array}$ & $2 \%$ & $35 \%$ & $2 \%$ & - & $40 \%$ & $23 \%$ \\
$\begin{array}{l}\text { Amount of } \\
\text { accrued } \\
\text { leave }\end{array}$ & $2 \%$ & $37 \%$ & $10 \%$ & $4 \%$ & $17 \%$ & $30 \%$ \\
\hline
\end{tabular}

either a reduction to, or abolition of, weekend pay rates; 33 percent had experienced either a reduction to, or the abolition of, pay rates for working outside normal hours (e.g. at night); and 25 percent had experienced a reduction to, or the abolition of, other special payment or allowances.

A surprisingly large number of respondents (32 percent) reported an increase in basic pay rates over the last two years but for most this did not translate into an increase in take home pay because of the changes to overtime and other working time arrangements. This is confirmed by the very strong relationship between changes to the number of hours worked and take home pay. Twenty percent of respondents reported that their overall take home pay had gone up but in nearly 40 percent of these cases that could be explained by an increase in hours worked.

There were some workers ( 10 percent of all respondents) who received increased basic pay rates and who were unaffected by changes to the overtime payments (probably because they had never worked overtime in the first place). 
This new data is important and useful as researchers try to piece together a more complete picture of labour market changes under the Employment Contracts Act. The Service Workers Union survey provides additional information looking at a group of women workers who, as predominantly part-time workers, frequently fall outside the existing research databases. These women were asked the same sets of questions as were those in the Heylen survey. The differing responses make for interesting comparisons and are presented in Table 6.

Table 6: Changed conditions: Service Workers and Heylen respondents

\begin{tabular}{||l|c|c|c||}
\hline & $\begin{array}{c}\text { Gone } \\
\text { Up }\end{array}$ & $\begin{array}{c}\text { Stayed } \\
\text { Same }\end{array}$ & $\begin{array}{c}\text { Gone Down/ } \\
\text { Abolished }\end{array}$ \\
\hline Basic Hourly Pay Rates & & & \\
Service Workers & $32 \%$ & $56 \%$ & $10 \%$ \\
Heylen Survey & $51 \%$ & $40 \%$ & $8 \%$ \\
Overtime Pay Rates & & & \\
Service Workers & $3 \%$ & $30 \%$ & $24 \%$ \\
Heylen Survey & $8 \%$ & $41 \%$ & $34 \%$ \\
Overall Take Home Pay & & & \\
Service Workers & $21 \%$ & $47 \%$ & $30 \%$ \\
Heylen Survey & $42 \%$ & $40 \%$ & $18 \%$ \\
\hline
\end{tabular}

Heylen respondents were more likely to report increases in basic hourly pay rates and overtime rates than were Service Workers. The combined effects of the various changed employment conditions had an impact twice as great for Service Workers than it did for those in the Heylen survey - with 42 percent of Heylen respondents reporting an increase in overall take home pay against 21 percent for the Service Workers. The women members of the Service Workers Union have fared demonstrably worse than those employees surveyed by Heylen. In part that finding can be explained by the way in which Heylen have presented their data. The data for hourly pay rates and overtime pay rates are based on a responses from 322 hourly wage earners whereas the data for overall take home pay are for the sample including salaried employees who being salaried would be far less affected by reductions and abolition of overtime payments (Heylen et al., 1992: 37).

\section{Conclusion}

The results from this survey indicate that many women in the service industry have not fared well under the Employment Contracts Act. The combined effects of new working time arrangements and for some, the lowering of base pay rates in new employment contracts has meant that 30 percent of those who responded have experienced a reduction 
in take home pay - and that finding may underestimate the true extent of the reductions experienced. The possibility of this underestimation comes about as the sample of respondents may not be representative of the union's total membership. The respondents on the whole are an older age group ( 60 percent are over 40 years of age) who have been in their present job for more than two years ( 85 percent). The survey attracted comparatively few responses from newly engaged workers who may be in the high turnover sections of the union. There is a definite skew away from workers in the hotel/hospitality and food/restaurant sector with just 16 percent of respondents being in either sector. Anecdotal evidence suggests that younger workers and those who have been with their employer for just a short period of time are the most likely to have experienced the largest reductions in employment conditions. If that were the case, then the results we present may indeed underestimate the extent of the reductions in employment conditions being experienced.

Whatever the true level of change in employment conditions, the data presented herein add further to the general picture that is being developed about the nature of labour market adjustment under the Employment Contracts Act. That the data presented are so different from that in the Heylen study causes one to ask questions about where labour market data is drawn from and just how much one must probe in order to a get true reflection of the actual situation - especially for groups that do not fit readily into existing datasets. The Heylen study surveyed a very heterogeneous population as noted above. The purpose of this study was to examine what changes, if any, had occurred within a relatively homogenous segment of the labour market. The contrast in results and conclusions does not call either study's methodology into question, but rather highlights the need for ongoing research into labour market adjustment under the Employment Contracts Act. It is harder than it was before to gain comprehensive information about working conditions because of the highly fragmented nature of bargaining under the Employment Contracts Act. For this reason, if no other, the data presented in this paper should be taken into account when pronouncing on labour market adjustments resulting from the Act.

\section{References}

Armitage, Craig and Dunbar, Richard (1993) Labour Market Adjustment under the Employment Contracts Act. New Zealand Journal of Industrial Relations, 18(1): 94-112.

Beechey, Veronica (1982), The Sexual Division of Labour and the Labour Process: A Critical Assessment of Braverman. In Wood, Stephen (ed.), The Degradation of Work? Skill, Deskilling and the Labour Process. London, Hutchinson.

Bervoets, Liesbeth and Frielink, Toby (1988), Feminists and the "Social Construction" of Skill. In Buitelaar, Wout (ed.) Technology and Work: Labour Studies in England, Germany and the Netherlands. Aldershot, Gower Publishing.

Blau, Francine and Kahn, Lawrence (1992) The Gender Earnings Gap: Some International Evidence. NBER Working Paper Series, Working Paper no. 4224, Cambridge MA, NBER. 
Cockburn, Cynthia (1981) The Material of Male Power, Feminist Review, 9: 41-58.

Cockburn, Cynthia (1983) Brothers, Male Dominance and Technological Change. London, Pluto Press.

Cockburn, Cynthia (1985) Machinery of Dominance: Women, Men and Technical KnowHow. London, Pluto Press.

Hammond, Suzanne and Harbridge, Raymond (1993) The Impact of the Employment Contracts Act on Women at Work. New Zealand Journal of Industrial Relations, 18(1): 15-30.

Heylen Research Centre and Teesdale Meuli and Co. (1992), A Survey of Labour Market Adjustment under the Employment Contracts Act 1991. Wellington, Industrial Relations Service, Department of Labour.

Phillips, Anne and Taylor, Barbara (1980) Sex and Skill: Notes Towards a Feminist Economics, Feminist Review, 6: 79-89.

Sayers, Janet (1991) Women, the Employment Contracts Act and Bargaining: A Discussion Paper. New Zealand Journal of Industrial Relations, 16(2): 159-166.

Terrell, Katherine (1992) Female-Male Earnings Differentials and Occupational Structure, International Labour Review, 131: 4-5.

Walby, Sylvia (1989) Flexibility and the Changing Division of Labour. In Wood, Stephen (ed.) The Transformation of Work? : Skill, Deskilling and the Labour Process, London, Unwin Hyman Ltd. 